\title{
Two serious complications of propylthiouracil treatment in the same patient - case report
}

Garrido, Susana ${ }^{1}$; Pereira, $T^{1}$; Ferreira, $\mathrm{MA}^{1}$; Caldas, $A R^{1}$; Silva, $\mathrm{AM}^{1}$; Teixeira, $\mathrm{S}^{1}$; Giestas, $\mathrm{A}^{1}$; Carvalho, $A^{1}$; Amaral, $C^{1}$; Freitas, $C^{1}$; Vilaverde, $\mathrm{J}^{1}$; Carvalho, $\mathrm{R}^{1}$; Marinho, $\mathrm{A}^{2}$; Borges, $\mathrm{F}^{1}$

${ }^{1}$ Serviço de Endocrinologia, Diabetes e Metabolismo, ${ }^{2}$ Unidade de Imunologia Clínica; Hospital de Santo António, Centro Hospitalar do Porto

\section{INTRODUCTION}

Thionamides are important drugs in the treatment of hyperthyroidism. Despite that, they can be associated with rare but serious complications, which require drug discontinuation.

\section{CASE REPORT}

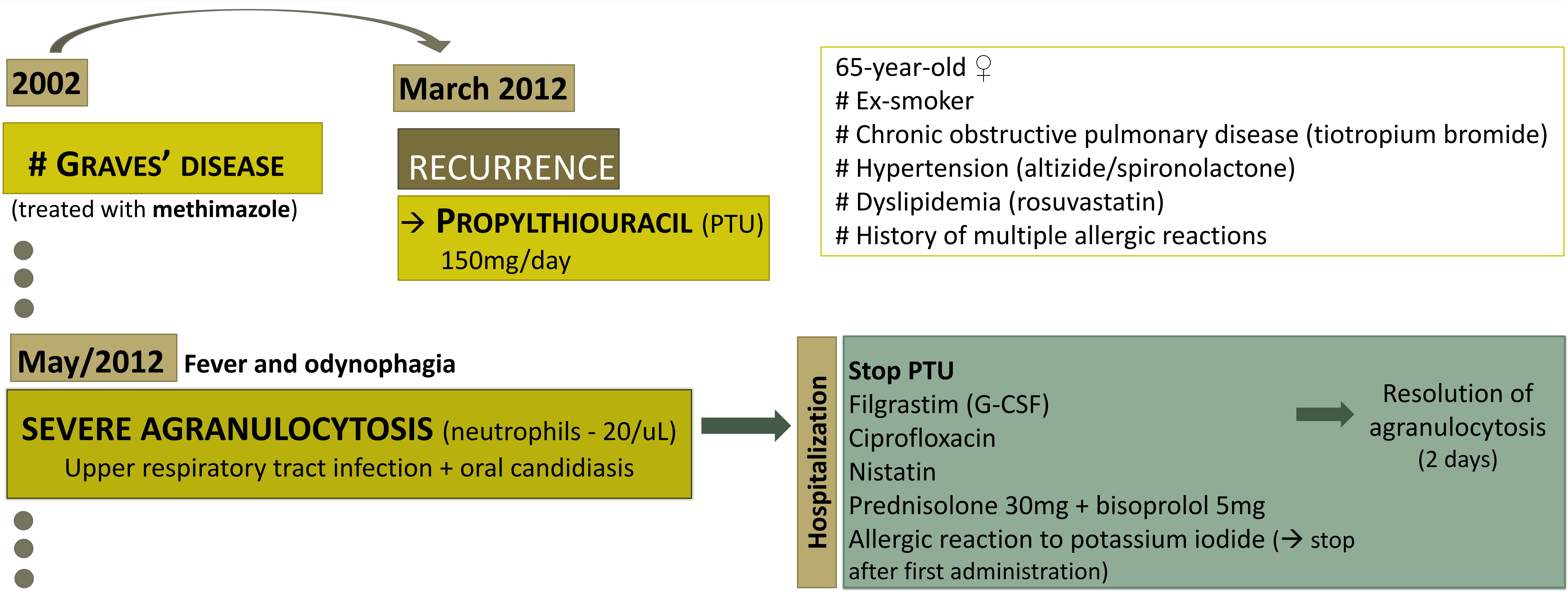

\section{2h after PTU suspension}

- Inflammatory signs of the submandibular glands $\rightarrow$ Bilateral sialoadenitis

- Severe epigastric abdominal pain, elevation of pancreatic enzymes $\rightarrow$ Acute pancreatitis (lipase $600 \mathrm{UI}$, amylase 624UI)

- Rash, palpable purpura, cutaneous ulcerations; cutaneous biopsy - leukocytoclastic vasculitis

- Dyspnea, bronchoconstriction, type 2 respiratory failure $\rightarrow$ CT scan - nonspecific interstitial

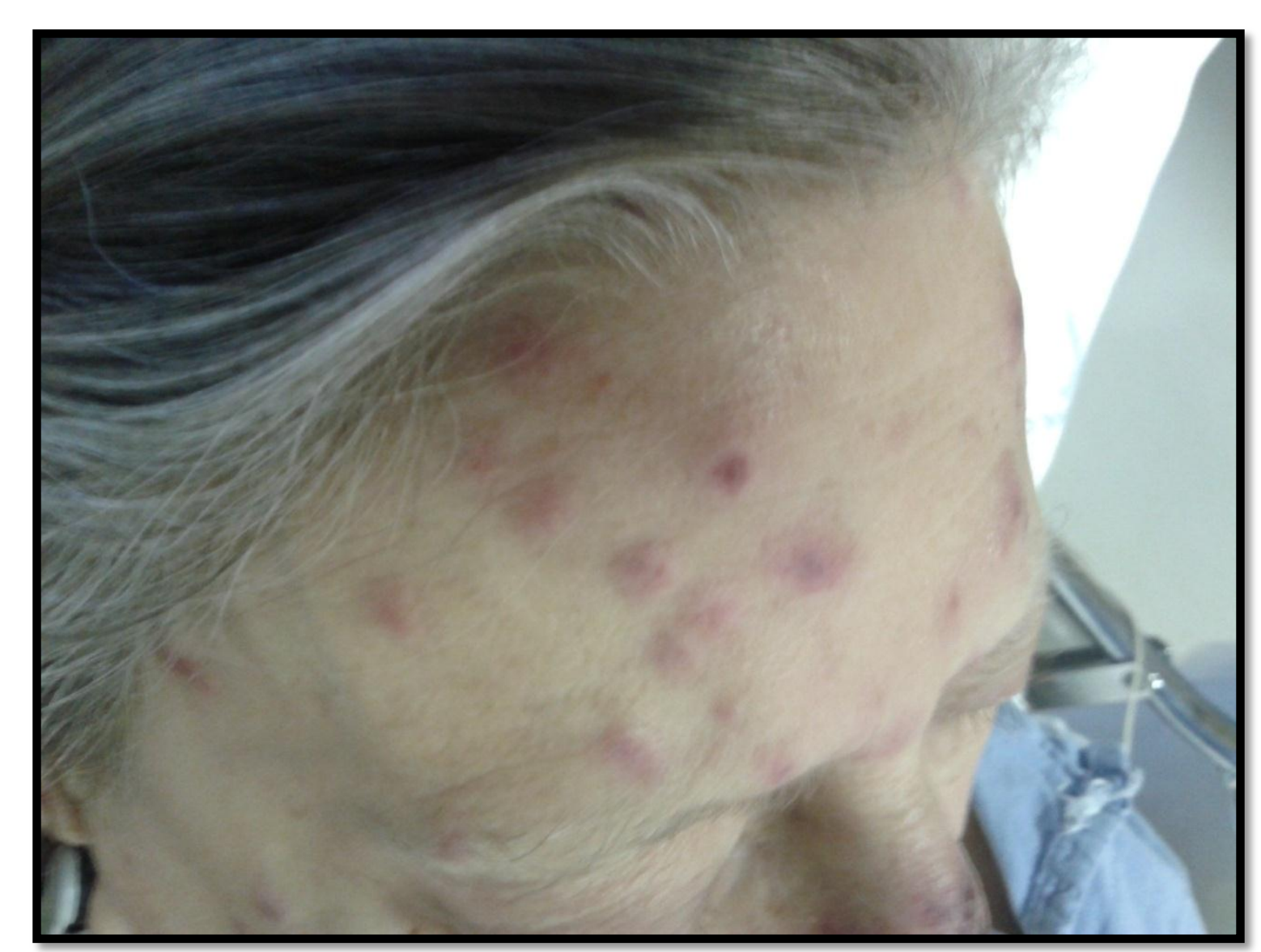
pneumonia

- Pancytopenia (neut 134/uL, Hb $6.3 \mathrm{~g} / \mathrm{dl}$, plat 126000/uL)

- Splenic infarct (asymptomatic, documented by CT scan)

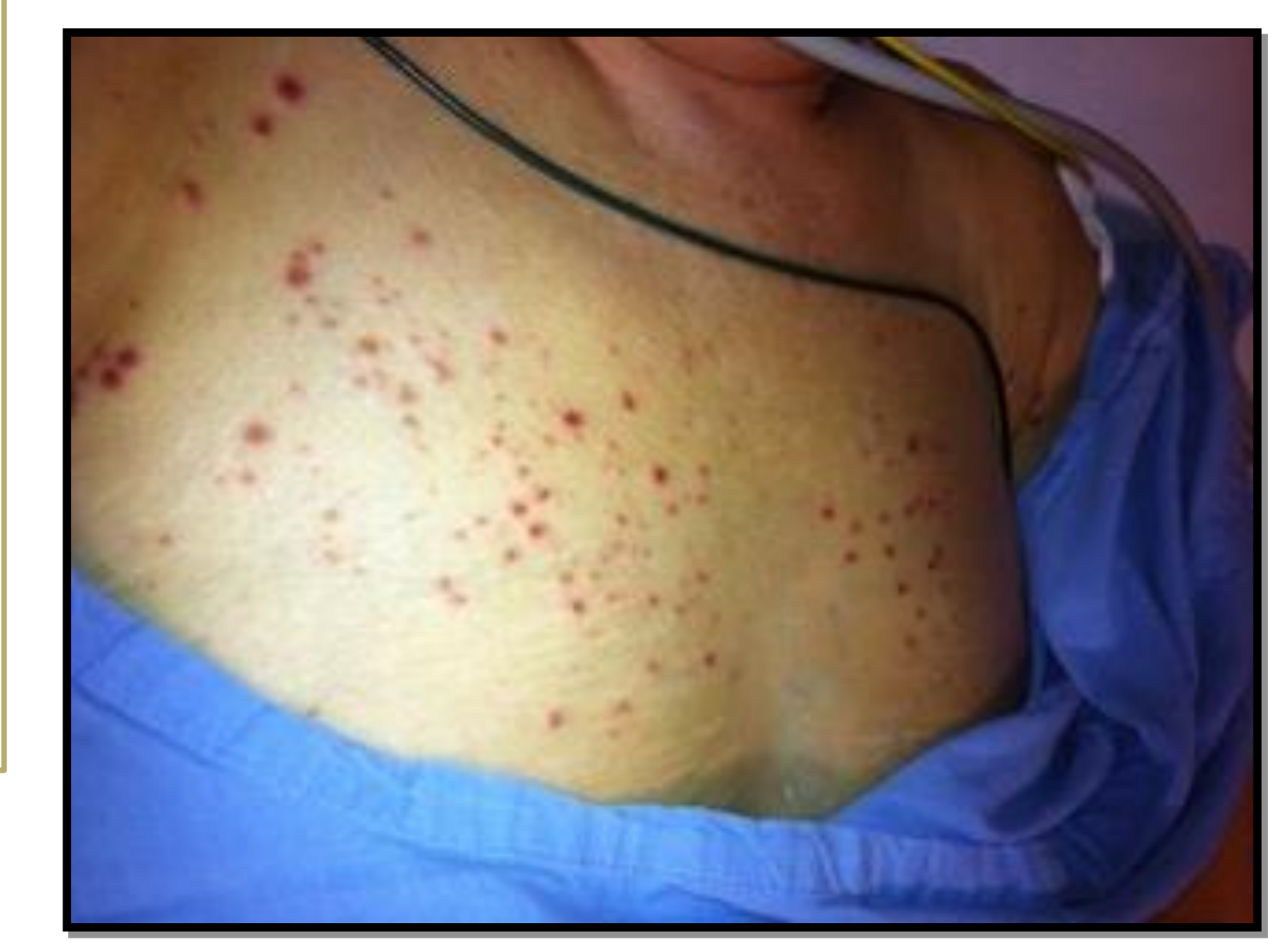

\section{Positive pANCA and MPO-ANCA antibodies}

Intensive Care Unit

Metilprednisolone $1 \mathrm{mg} /$ day (3 days) $\rightarrow$ Prednisolone $1 \mathrm{mg} / \mathrm{kg} /$ day

Total thyroidectomy

Day 51 Hospital discharge
- Extensive cutaneous ulcers $\rightarrow$ Autologous skin grafting

- Myopathy (critical illness + corticotherapy) $\rightarrow$ Physical Medicine

Favorable evolution and resolution of organ dysfunctions and Rehabilitation Center

- Glucocorticoid tapering, without clinical worsening

- Negative ANCA and MPO-ANCA antibodies 